\title{
Kaleidoscope in Jazz Age: On Symbolic Meanings of Colors in The Great Gatsby
}

\author{
SUN Xiao-fang \\ Shenzhen Polytechnic, Shenzhen, China
}

\begin{abstract}
F. S. Fitzgerald is one of the greatest American novelists and his work, The Great Gatsby is the paradigmatic writing of Jazz Age. In the fiction, the symbolic representation of colors is more strikingly exhibited, which is part and parcel of the total artistic achievement of this masterpiece. This essay intends to explore the symbolic meanings of colors in the novel, suggesting that the color imagery contributes to reproducing the kaleidoscope in the magnificent social life of Jazz Age and implies the inevitable disillusionment of the protagonist's American dream that is defined as his pursuit of romantic love with Daisy, further intertwined with the search for a personal grail.
\end{abstract}

Keywords: The Great Gatsby, symbolic meanings of colors, kaleidoscope

\section{Introduction}

Francis Scott Key Fitzgerald (1896-1940) is one of the greatest American novelists and short story writers, whose works are the paradigmatic writings of Jazz Age, a term he coined himself. He is generally regarded as the spokesman of the 1920s, the peculiar decade that combined the postwar economic boom and the sense of spiritual disorientation. He was both a leading participant in the typically pleasure-seeking and money-making life of the 1920s, and a self-conscious writer with detached observation of it. Fitzgerald was considered a member of the "Lost Generation" of the 1920s and his fictions reveal the hollowness of the American worship of riches and the unending American dreams of love and splendor and gratified desires.

Fitzgerald has completed four novels, The Side of Paradise (1920), The Beautiful and Damned (1922), The Great Gatsby (1925), and Tender Is the Night (1934), among which The Great Gatsby has been regarded as his masterpiece. It is a novel set against the ending of the World War I. Nick Carraway, the narrator of the story, is a young Midwesterner who sells bonds in New York. He lives at West Egg, Long Island, which is separated from the city by an ash-dump. His neighbor, Jay Gatsby is a mysterious man, whose mansion and fabulous entertainments are financed by bootlegging and other criminal activities. When he was a poor army lieutenant, Gatsby had fallen in love with Nick's cousin, Daisy who however married a wealthy man named Tom Buchanan. Thus Gatsby manages to meet Daisy again with the help of Nick and tries to win her back with his extravagant devotion. Meanwhile, Daisy’s husband takes another woman, Myrtle Wilson, as his mistress, who is accidentally hit to death by the car driven by Daisy. To protect Daisy, Gatsby ends up with being shot by Myrtle's husband.

As a masterpiece in American literature, The Great Gatsby is rich in symbolism which functions in a variety of ways thus it is fully integrated into the plot and structure, even the symbols seem naturally to "grow

SUN Xiao-fang, Associate Professor, School of Applied Foreign Languages, Shenzhen Polytechnic. 
out of the action rather than existing as mere abstractions” (Balling, 1967, p. 12). And, the symbolic representation of colors is more strikingly exhibited in the fiction, which is part and parcel of the total artistic achievement of the book. This essay intends to explore the symbolic meanings of colors in the novel, suggesting that the color imagery contributes to reproducing a scenic kaleidoscope in the magnificent social life of the Roaring Twenties and implies the inevitable disillusionment of the protagonist's American dream that is defined as his pursuit of romantic love with Daisy, further intertwined with the search for a personal grail.

\section{Kaleidoscope in Jazz Age: A Colorful World Replaced in The Great Gatsby}

Whoever has read the story would be deeply impressed by the visional "green light" emitted from East Egg and constantly stared by a figure from West Egg in the opening chapter. At the outset, the narrator hasn't provided us any information of the protagonist, instead, he just offers us a mysterious picture,

I saw that I was not alone-fifty feet away a figure had emerged from the shadow of my neighbor's mansion ... he stretched out his arms toward the dark water in a curious way ... a single green light, minute and far away, that might have been the end of a dock. ${ }^{1}$ (Fitzgerald, 1980, p. 22)

Green is the color of hope and future. The green light, which is here situated at the end of Daisy's East Egg dock and barely visible from Gatsby's West Egg lawn, represents Gatsby's hope and dream for the future that is associated with Daisy. This green dream is originally set in Gatsby's boyhood and fully shaped in Gatsby's adulthood when he meets with the dazzling beautiful girl, Daisy. Actually what is his dream? Born in a poor German immigrant family, Gatsby has been longing to change his destiny by making fortune and stepping into the upper class with his efforts. When he comes across Daisy who is from the noble and wealthy family, Gatsby, in his early twenties, is enchanted by this lovely girl and falls in love with her at the first sight. To realize his dream, Gatsby makes a good fortune from the illegal business and spends a large amount of money taking extravagant parties to attract Daisy to come to his mansion in West Egg. This symbol, green light, which can be illustrated from its long history, looks full of expectations, imaginations and deep meanings. Though the color green makes relatively few appearances in the novel, Fitzgerald succeeds in using this symbol to lead his main theme out and to impress readers heavily at the outset.

Nevertheless, it is believed that "the ironic use of color imagery and symbolism can perhaps best be illustrated by Fitzgerald's use of white” (Elmore, 1970, p. 440). White is always applied to East Egg and characters from East Egg, especially to Daisy. It is known that "daisy" is a kind of small white flower with a yellow center. On his first visit to the Buchanans’ mansion in chapter I, Nick finds:

The only completely stationary object in the room was an enormous couch on which two young women were buoyed up as though upon an anchored balloon.

They were both in white, and their dresses were rippling and fluttering as if they had just been blown back in after a short flight around the house. (Fitzgerald, 1980, p. 3)

The white color symbolizes purity and innocence which offers people the vision of fairies and in the belief of Gatsby, Daisy's white dress rightly represents the ideal lover and princess residing in the old castle. On that occasion, "the heavenly whiteness of East Egg begins as a symbol of beauty, goodness, and truth as Nick attempts to be faithful to Gatsby's vision of Daisy's world” (Elmore, 1970, p. 440). In that white palace,

\footnotetext{
1 All the quotations from The Great Gatsby are quoted from F. S. Fitzgerald, The Great Gatsby, New York: Macmillan Publishing House, 1980. Further references are seen in the parentheses.
} 
particularly the pervasively white mansion of the Buchanans, Daisy is associated with white dress, white roadster, and she talks endlessly about the white race. The whiteness symbolized by Daisy here may deeply suggest more than purity in nature, but nobleness and sacredness, the signal of the upper class. In her white dress, Daisy recalls her "white girlhood," and this use of color helps to characterize her as the unattainable "enchanted princess" who becomes incarnate as Gatsby's dream that can be well defined as his pursuit of romantic love with Daisy, intertwined with desire for a higher social class. It is worthwhile noting that apart from the symbolic meaning of purity and nobleness, the color white rightly implies emptiness and illusion that signifies the genuine nature of Daisy (ZHANG, 1999, p. 11). As a matter of fact, originally "high in a white palace” as the king's daughter, she is still the golden girl, and even her voice is like money. According to the narrator, Nick Caraway, Gatsby, who devotes his heart and soul for his goal, is mentally superior to Daisy and her husband:

They were careless people, Tom and Daisy-they smashed up carelessness, or whatever it was that kept them together, and let other people clean up the mess they made... (Fitzgerald, 1980, p. 180)

Compared with these words, Nick definitely praises Gatsby by remarking: "They're a rotten crowd; you are worth the whole damn bunch but together" (Fitzgerald, 1980, p. 162). In particular, when Daisy refuses to participate in the funeral of Gatsby who has been murdered because of his voluntary scapegoating himself for the sake of Daisy, Nick has found how utterly inhuman the Buchanans really are and what an ugly and evil character their whiteness truly carries. Gatsby fails to see through his Fairy-princess' pure and charming outward expression and can't find her sophisticated and mean inward content but persistently pursues her, which undoubtedly leads to his pathetic tragedy. On the other hand, originated from the rising lower class, Gatsby also fails to recognize the brutality of the noble Anglo-Saxon white race who definitely forbids the new immigrants from entering their circle. To the Buchanans who represent the rich, old family of the Anglo-Saxon, Gatsby, a leading figure of the new force, is only nobody from nowhere. Failing to fathom the true nature of Daisy and the upper class, Gatsby is heavily obsessed with his American dream and doomed to die for it willingly.

It is not difficult to observe that "yellow makes more appearances than any other single color except white, and both yellow and gold are applied predominantly to West Egg and in particular to Gatsby" (Elmore, 1970, p. 435). At the party, "there was music from my neighbor's hones through the summer nights. In this blue garden men and girls came and went like moths" (Fitzgerald, 1980, p. 39). Gatsby's parties in the blue garden are used to attract his ideal lover, but the romantic blue is unavoidably full of the material color of money-yellow. For example, "in the main hall a bar with a real brass rail was set up" (Fitzgerald, 1980, p. 40) where the narrator often could meet the young ladies "in yellow dresses", even "the orchestra is playing yellow cocktail music" (Fitzgerald, 1980, p. 40). And at the party, "the moon had risen higher, and floated in the sound was a triangle of silver scales, trembling a little of the stiff, tinny drip of the banjoes on the lawn” (Fitzgerald, 1980, p. 47). Even the death car, Gatsby's Rolls-Royce, that strikes down Myrtle Wilson proves to be yellow, the most conspicuous and pervasive color. Undoubtedly, this vividly depicted picture, on one hand, unfolds an authentic style of the Jazz Age exemplified by such elements as parties, beauties, cocktail, lavish houses, expensive cars and intangible emptiness. Ironically, this car in the color of money always carries its owner, Gatsby, who possesses romantic dreams. It is doomed that this materialistic vehicle carrying an idealist can never arrive at its destination in the age of unbelief and vast carelessness. On the other side, these extravagant parties always 
serve as a colorful dreamland for Gatsby to submerge in his ideal dreaming and his silk shirts in all kind of colors: pink, apple-green and so on help to knit this beautiful dream. Nevertheless, the parties held in the romantic blue garden, have to be filled with colors of material-brass, yellow, silver. This kind of mixture of idealism and materialism certainly leads to the illusion and failure of the ideal dream. This tragedy, to some extent, has been shown through the presence of all the dazzling, fresh colors that can never survive in the ugly and sophisticated world.

Opposite to his dreaming world, there exists a real society,

...about half way between west Egg and New York the motor road hastily joins the railroad and runs besides it for a quarter of a mile, so as to shrink away from a certain desolate area of land. This is a valley of ashes ... where ashes take the form of houses and chimneys and rising smoke, finally, with a transient effort, of ash-gray men. Occasionally a line of gay cars crawls along an invisibly track, gives out a ghastly creak, and comes to rest, and immediately the ash-gray men swarm up with leaden spades and stir up an impenetrable cloud, which screens their obscure operations from your sight. (Fitzgerald, 1980, p. 23)

Here, the valley of gray ashes represents the wasteland or the moral and social decay resulting from the inhibited pursuit of wealth. And the rich like the Buchanans only indulge themselves with regard for nothing but their money and pleasure. Gray, the symbol of wastes and ashes, can be profoundly interpreted as the theme of degraded moral wilderness in the upper class. In this moral vacuum, a man from the lower class can't survive and George Wilson's unfortunate career illustrates the fate of the common man in this wasteland. And Gatsby with the similar origin can't survive it as well.

Opposite to Gatsby stands Tom Buchanan, who possesses the air of arrogance and brutality and "was a body capable of enormous leverage.” To Tom, his mistress, Myrtle Wilson is merely an idol from a lower class. When he attacks Myrtle, only by calling her name, he would beat her badly and "there were bloody towels upon the bathroom floor...." Red, the color of blood illustrates accurately the brutality and cruelty of Tom. Being Tom's mistress, Myrtle can’t enter his class and even can't change her tragic fate-being died in the valley of ashes and whose "thick dark blood" mixed with the dust of the Valley of ashes-the foul dust which floats in the wake of Gatsby's dreams. Later on, Wilson kills Gatsby, whose blood leaves "a thin red circle in the water". The beautiful reds, as the color of roses, suddenly change into the color of violence. And the violence is caused by the Buchanans - the beautiful, fairy-like wife and the upper-class rich husband. The color of red completely tears the covers of the so-called noble persons-Daisy and Tom, meanwhile dyes the quality of the moral person-Gatsby more charming.

\section{Conclusion}

Fitzgerald is a great stylist in American literature. His accurate dialogues, his original diction and metaphor and his impressionistic quality provide readers with a vivid sense of reality. Particularly, the artistic employment of color symbolism helps to reproduce a scenic kaleidoscope-a colorful and violent world of the “Jazz Age” in 1920s more vividly, which greatly deepens the moral loaded in the work-disillusionment of Gatsby's America dream and failure of his personal grail. Green, color of hope; white, color of purity; blue, color of romance; yellow, silver, brass, colors of material; gray, color of decay; red, color of brutality. All these colors are applied and mixed to paint a prosperous picture of the American society and the "characters are more than the sum of their own experiences: they constitute America itself as it moves into the Jazz Age" (Berman 2001, p. 54). Like a kaleidoscope, these colors only represent beauty and variety of the Roaring Twenties, but if 
they can't manage them well, can't fathom the other side of them-emptiness, violence, decay, people in Jazz Age will become confused in the dazzling colors. And Gatsby is such a paradigm, who is overwhelmed with the green color and ultimately bewildered in pursuing the emptiness of his dream.

\section{References}

Balling, F. J. (1967). Cliffs notes on Fitzgerald's The Great Gatsby. Lincoln: University of Nebraska Press.

Berman, R. (2001). Fitzgerald, Hemingway, and the Twenties. Tuscaloosa: The University of Alabama Press.

Cooperman, S. (1996). F. Scott Fitzgerald's The Great Gatsby. Beijing: Foreign Language Teaching and Research Press.

Elmore, A. E. (1970). Color and Cosmos in The Great Gatsby. The Sewanee Review, 78(3), 427-443.

Fitzgerald, F. S. (1980). The Great Gatsby. New York: Macmillan Publishing Company.

Mizener, A. (1979). F. Scott Fitzgerald's The Great Gatsby. In Voice of America (Ed.), Forum: The American novel. Washington D.C.: United States International Communication Agency.

Schneider, D. J. (1970). Color-symbolism in The Great Gatsby. In H. D. Piper (Ed.), Fitzgerald's The Great Gatsby. New York: Charles Scribner's Sons.

ZHANG, R. H. (1999). The symbolic meanings in The Great Gatsby. Foreign Literature Studies, (2), 9-12. 